\title{
How Blue Carbon Ecosystems Are Perceived by Local Communities in the Coral Triangle: Comparative and Empirical Examinations in the Philippines and Indonesia
}

\author{
Jay Mar D. Quevedo ${ }^{1}\left(\mathbb{D}\right.$, Yuta Uchiyama ${ }^{2}{ }^{\mathbb{D}}$, Kevin Muhamad Lukman ${ }^{1} \mathbb{C}$ and Ryo Kohsaka ${ }^{2, *}$ \\ 1 Graduate School of Environmental Studies, Tohoku University, Sendai City 980-8572, Japan; \\ quevedojaymar@gmail.com (J.M.D.Q.); kevin.muhamad.lukman@gmail.com (K.M.L.) \\ 2 Graduate School of Environmental Studies, Nagoya University, Nagoya City 464-8601, Japan; \\ uchiyama.yuta@k.mbox.nagoya-u.ac.jp \\ * Correspondence: kohsaka@hotmail.com
}

Citation: Quevedo, J.M.D.; Uchiyama, Y.; Muhmad Lukman, K.; Kohsaka, R. How Blue Carbon Ecosystems Are Perceived by Local Communities in the Coral Triangle: Comparative and Empirical Examinations in the

Philippines and Indonesia.

Sustainability 2021, 13, 127.

https://dx.doi.org/10.3390/su13010127

Received: 19 October 2020

Accepted: 22 December 2020

Published: 24 December 2020

Publisher's Note: MDPI stays neutral with regard to jurisdictional claims in published maps and institutional affiliations.

Copyright: () 2020 by the authors. Licensee MDPI, Basel, Switzerland. This article is an open access article distributed under the terms and conditions of the Creative Commons Attribution (CC BY) license (https: / / creativecommons.org/ licenses/by/4.0/).

\begin{abstract}
Blue carbon ecosystem (BCE) initiatives in the Coral Triangle Region (CTR) are increasing due to their amplified recognition in mitigating global climate change. Although transdisciplinary approaches in the "blue carbon" discourse and collaborative actions are gaining momentum in the international and national arenas, more work is still needed at the local level. The study pursues how BCE initiatives permeate through the local communities in the Philippines and Indonesia, as part of CTR. Using perception surveys, the coastal residents from Busuanga, Philippines, and Karimunjawa, Indonesia were interviewed on their awareness, utilization, perceived threats, and management strategies for BCEs. Potential factors affecting residents' perceptions were explored using multivariate regression and correlation analyses. Also, a comparative analysis was done to determine distinctions and commonalities in perceptions as influenced by site-specific scenarios. Results show that, despite respondents presenting relatively high awareness of BCE services, levels of utilization are low with $42.9-92.9 \%$ and $23.4-85.1 \%$ respondents in Busuanga and Karimunjawa, respectively, not directly utilizing BCE resources. Regression analysis showed that respondents' occupation significantly influenced their utilization rate and observed opposite correlations in Busuanga (positive) and Karimunjawa (negative). Perceived threats are found to be driven by personal experiencesoccurrence of natural disasters in Busuanga whereas discerned anthropogenic activities (i.e., land-use conversion) in Karimunjawa. Meanwhile, recognized management strategies are influenced by the strong presence of relevant agencies like non-government and people's organizations in Busuanga and the local government in Karimunjawa. These results can be translated as useful metrics in contextualizing and/or enhancing BCE management plans specifically in strategizing advocacy campaigns and engagement of local stakeholders across the CTR.
\end{abstract}

Keywords: blue carbon ecosystems; coral triangle; Philippines; Indonesia; local perceptions

\section{Introduction}

Coastal ecosystems are among the most productive ecosystems; offering beneficial services that enhance people's well-being and supporting local communities and national economies [1,2]. Among these services are food provision, habitat for commercially important species [3], coastal protection [4], and cultural services [5]. Another key service coastal wetlands provide that was overlooked in the past is the regulation of the global climate; currently referred to as "blue carbon" [6]. This concept recognizes the vital role of the coastal wetlands as buffers to the adverse effects of the changing, in this case, increasing, world atmospheric carbon dioxide levels [7]. This is possible through the thriving photosynthetic organisms in coastal ecosystems that extract carbon dioxide directly from the atmosphere and surface waters [8,9]. Mangroves, seagrass meadows, and tidal marshes, collectively called blue carbon ecosystems (BCEs), sequester and store carbon dioxide as 
organic carbon in their biomass (above and below ground) and soil material [10,11]. BCEs may carry out this process continuously for over thousands of years, locking away carbon that could contribute to the heating of the earth's atmosphere into a large number of carbon stocks in biomass and organic-rich soils [6].

One of the world's richest hotspots of marine biodiversity lies in the Coral Triangle Region (CTR) [12], where Indonesia and the Philippines are geographically located. In terms of BCEs in the region, Indonesia has the largest mangrove and seagrass coverage, around 2,707,572 ha [13] and 3,000,000 ha [14], respectively, whereas the Philippines has roughly 256,185 ha of mangrove forests [15] and 97,800 ha of seagrass meadows [16]. Tidal marshes are not found in these countries since they thrive in mid- to high-latitude regions [17]; ranging from arctic to subtropical regions [18]. The degradation of coastal wetlands in the Philippines and Indonesia could result in discernable loss of beneficial services such as food sources, protection against storm surges, and cultural services [19-21]. Moreover, as BCEs are in decline, their intangible and long-term service of carbon sequestration and storage are likely to be affected as well. A large number of carbon stocks sequestered over the years in Indonesia and the Philippines are threatened to be released back into the air, contributing to the further rising of global temperature, if these ecosystems continue to be degraded and lost [22,23]. Much of the deterioration of these coastal resources is mostly anthropogenic, particularly due to land-use conversion [1,24,25].

In response, researchers, policymakers, and implementers are gearing towards building a strong foundation of science, policy, and sustainable coastal management practices for the conservation and restoration of BCEs as a means of collective effort in addressing climate change [6]. Some of the recent advances on blue-carbon-related studies in the Philippines and Indonesia include carbon stock assessment and carbon sequestration potential [14,26,27], policies and finance mechanisms [28-30], and public's perceptions [31-34]. Collaborative workshops and other initiatives on blue carbon involving these two countries along with other members in the CTR are also progressing (i.e., [6,35]). There is the International Partnership for Blue Carbon (IPBC) established during the Paris Agreement, UNFCCC COP21, in 2015, which was aimed at connecting efforts of research organizations, governments, non-government and international organizations in enhancing the protection and restoration of BCEs [36]. Such partnerships can foster and strengthen the relationships of the involved countries by sharing knowledge, experiences, and expertise in understanding better the importance of BCEs in global climate regulation and adaptation, achieving sustainable development goals, growing the blue economy, and meeting national commitments to the Paris Agreement [6].

Despite the gaining momentum of the "blue carbon" discourse and collaborative actions in the international and national arenas, more work is still needed at the local level especially where local governments, implementers, and residents are the ones interacting with-benefiting from and taking advantage of resources from-these ecosystems. This work pursues how BCE initiatives permeate through the local communities in CTR, particularly in the countries of Indonesia and the Philippines using perception inquiries. Local perceptions, based on comprehensive theoretical and empirical evidence, have a critical role in supporting collective responses for the sustainable management of natural resources (i.e., [34,37]). Engaging local communities in ecosystem service assessments helps define their role in the multi-governance of environments as well as the importance of ecosystem services (ES) and the factors that influence social preferences and trade-offs related to land-use change and decision-making [38]. ES in this study is based on the definition of [38] which refers to the benefits people obtain from ecosystems. These include provisioning services (i.e., food), regulating services (i.e., climate regulation), cultural services (i.e., recreational benefits), and supporting services (i.e., habitat). Local's perception of ES is a very subjective process - it can be based on their comprehension, interpretation, and experiences. There is also a concern of how ES provides well-being and how these benefits are valued, whether as an "instrumental" value when attributed to a particular purpose or as a "relational" value when used to measure certain types of interactions, by society [39]. 
For instance, some locals may recognize cultural services based on their aesthetic, educational, and therapeutic values [40] while others based on the accessibility and proximity of the resources (i.e., tourism sites) [41]. There is also a shift at the conceptual level which is focusing more on "indirect drivers" in ES assessments although "direct drivers" are still largely highlighted in frameworks such as the Driver-Pressure-State-Impact-response (DPSIR) [42,43]. Indirect drivers (i.e., demographic, economic, socio-political, cultural) can heavily influence locals' perceptions and attitudes towards the environment with subsequent environmental implications (positive or negative).

In this study, people's awareness level, utilization rates, perceived threats, and management strategies were gathered and used as proxies in determining the familiarity of coastal communities to BCEs, which in turn could reflect the current management directives at a local scale in the Philippines and Indonesia in CTR. The people's awareness and utilization of ES in this work are closely associated with assessing the instrumental value of the benefits (i.e., food provision, recreation) since these benefits allow people to achieve a good quality of life [39]. "Relational" values, which are equally important, were not assessed since this involved a thorough examination of the relationship between the people and nature, like determining their specific principles or moral duties on how they can relate to nature [39]. Socio-demographic characteristics were factored in, since previous studies have shown their effect on an individual's perceptions [33,37]. Furthermore, a comparative analysis was done to determine distinctions and commonalities in perceptions as influenced by site-specific scenarios. These perceptions can be translated to become useful metrics in contextualizing and/or enhancing coastal management plans specifically in strategizing advocacy campaigns and engagement of local stakeholders. Up until recently, there has been a preference for a bottom-up approach in management and governance in the Philippines and Indonesia. How the study underscores local perceptions could also contribute to this grassroots/community-based and informed course of action for the national level to highly consider and prioritize. The availability of this information across the CTR could be a sound foundation to compare and contrast how coastal communities from different countries perceive and value their resources. This crucial learning could then be furthered into identifying common grounds that can be transferrable across or translated into a contextualized regional program within the CTR.

\section{Research Methods}

\subsection{Study Sites}

This study was conducted in the municipality of Busuanga in Busuanga Island, Palawan province, Philippines, and Karimunjawa Island, Jepara Regency, Indonesia (Figure 1). The two sites present a good opportunity to show how locals perceive BCEs, their services, and management status because of large communities depending on them. Both sites have relatively the same characteristics (i.e., economic activities, presence of a zonation system, and different stakeholders) that could potentially influence communities' perceptions. These site-specific settings can reflect how BCEs are locally managed, which is critical to understanding and achieving sustainability goals across the CTR.

In terms of economic activities, $70 \%$ of the activities in Busuanga town comes from fishing, forestry, and agriculture [44] while 74\% comes from fishing and farming in Karimunjawa Island [45]. Fishing-related activities in the sites can be supported by the presence of BCEs: the former has an estimated 4738 ha of mangroves and 3726 ha of dense and sparse seagrass beds [44] while the latter has roughly 400 ha of mangroves and 404 ha of seagrass meadows [46]. Despite the economic importance, BCEs in the sites are still subjected to a lot of human-derived stresses (i.e., illegal cutting), thus, several management schemes are in place to protect and conserve them. For instance, Busuanga Island has been identified as a partially protected key biodiversity area (KBA) along with Calauit, Culion, and Coron Islands [47] with an ecological zoning plan being followed under the strategic environmental plan (SEP or Republic Act No. 7611). The environmental conservation in the island is, among others, governed by a special institution called the Palawan Council 
for Sustainable Development (PCSD). Meanwhile, Karimunjawa Island, along with the 26 islands, comprise the Karimunjawa National Park (KNP), a protected marine park, which was established under the Plantation Decree no. 78/kpts-II/1999 by the Ministry of Forestry [48]. A stringent zoning system that consists of eight zones is implemented on the island [48]. The zonation system in the sites governs where and how the coastal resources should be used.

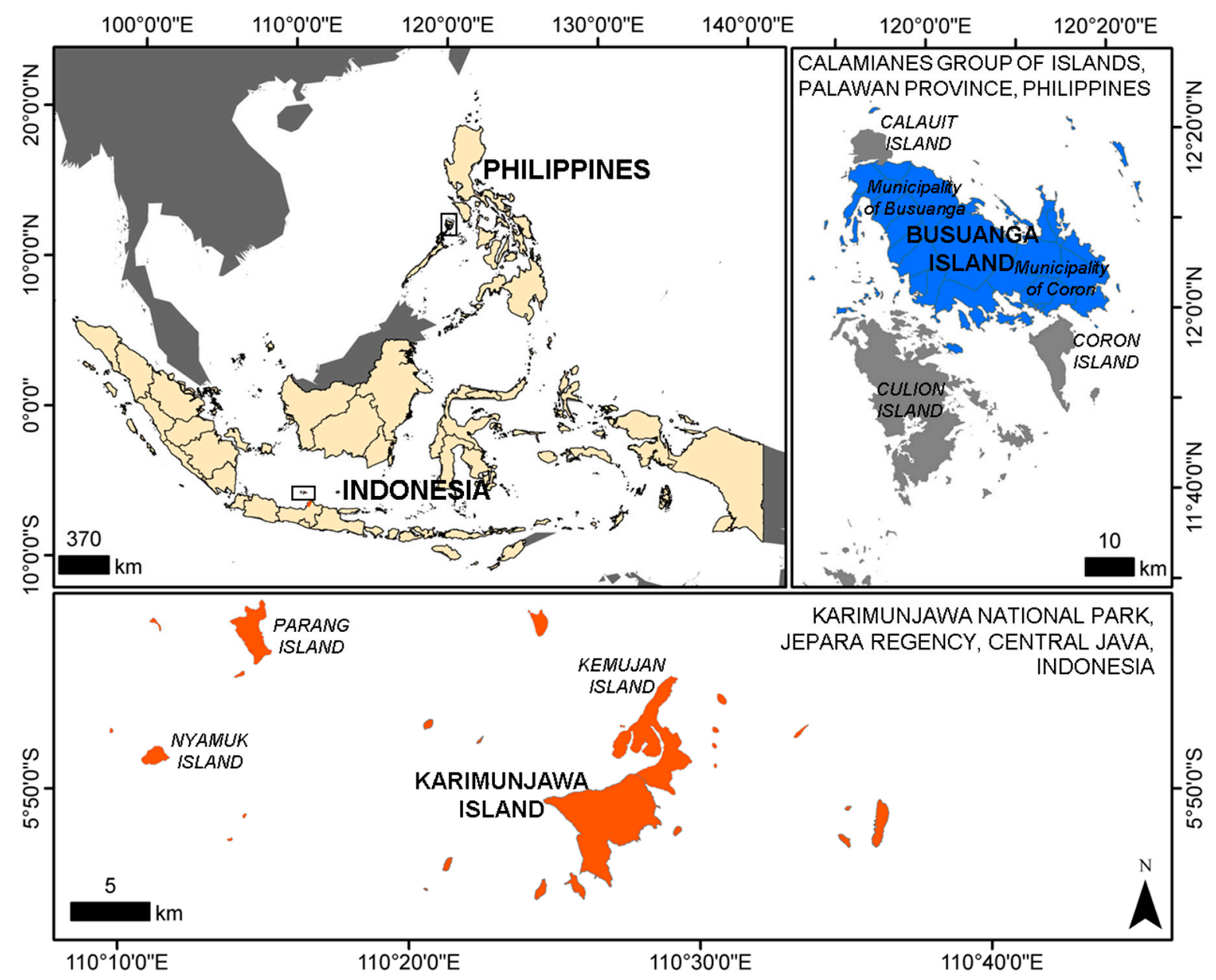

Figure 1. Location map of the study sites.

The sites also reflect the potential role of different stakeholders like local residents, people's organizations (POs), non-government organizations (NGOs), government agencies, and private sectors in the management of BCEs. In Busuanga, the municipal agriculture office (MAO) is in charge of the management of land and marine resources of the town. Following the mandates from the provincial and national offices, the MAO oversees programs and collaborations with other agencies. The MAO directly supervises the barangay fisheries and aquatic resources management council (BFARMC) and coordinates with POs (i.e., fishers' associations). The presence of these grassroots-led groups encourages the active participation of the community in management-related activities [49]. Another important stakeholder present in Busuanga is C3 Philippines, an NGO which empowers local communities to manage sustainably their coastal resources. These various groups in Busuanga are important in achieving a better integrated coastal management system [49]. Meanwhile, in Karimunjawa, the work of [50] has documented that $67.74 \%$ of managementrelated activities in the island are performed by relevant government agencies like Balai Taman Nasional Karimunjawa while a small fraction belongs to residents or community and NGOs, about $22.6 \%$ and $8.6 \%$ of the activities, respectively. Government agencies usually lead and collaborate with other organizations to conduct activities on the island. 
For instance, Karimunjawa National Park Authority has collaborated with NGOs like the Wildlife Conservation Society (WCS), Taka (local), and the University Diponegoro in conducting spatial planning and stakeholder consultation processes to revise the zoning system [48]. On the other hand, community-led and NGO-led activities are often limited since they are dependent on funding agencies [50].

\subsection{Sampling and Survey Procedures}

Identification of the survey sites followed the criteria of [33]: the presence of BCEs, the proximity of coastal communities, and accessibility of the village. The interviews were conducted in the municipality of Busuanga in Busuanga Island and in Karimunjawa Island in KNP (Figure 1). Given the set conditions, the respondents were selected randomly; surveying one household in every five-household interval where possible [33,34]. Also, stating the purpose of the survey and asking the permission of each respondent was carefully observed. Furthermore, field enumerators who are associated with the respective government units assisted in the conduct of the surveys. For clarity and consistency purposes in presenting the results and discussions, the sites will be delineated simply as "Busuanga" and "Karimunjawa".

The sample size computation was carefully done to get an appropriate representation of the populations and reliable inferences [51]. Although a sample size with the smallest margin of error (i.e., 2-5\%) will always be considered a good representative of the population [52], the level of precision could also depend on the amount of risk a researcher is willing to accept [51]. Thus, in this study, we calculated the sample size in each site at a 95\% confidence level with a 10\% sampling error using Cochran's formula [53]: $\mathrm{n}=\mathrm{n}_{0} /\left(1+\mathrm{n}_{0} / \mathrm{N}\right)$, where $\mathrm{n}_{0}=\left(\mathrm{t}^{2} * p * q\right) / \mathrm{d}^{2}$, and $\mathrm{t}=$ value of selected alpha level (in this study, $\alpha$ is 0.05 , so the critical value is 1.96), $p=$ estimated proportion of the population which has the attribute in question, $q=1-p$, and $\mathrm{d}=$ acceptable margin of error (in this study, 0.10), and $\mathrm{N}=$ population size (22,046 for Busuanga [54] and 9249 for Karimunjawa [45]). The confidence interval of $95 \%$ and the margin of error of $10 \%$ were selected based on previous works on household surveys (i.e., [33,34]).

A total of 98 locals were randomly interviewed in Busuanga from 19-25 July 2019 whereas only 47 residents were surveyed in Karimunjawa from 8-12 October 2019. Due to limited time in the field survey in Karimunjawa, we were only able to interview 47 respondents instead of 95 people, which is based on our sample size calculation. Due to this, the sampling error for Karimunjawa has increased to $14 \%$ from the planned $10 \%$ margin of error. We accepted this risk and limitations in accordance with the principles of [51] and the value of internationally comparative survey results was considered and the results were used in this study, carefully considering the difference in the levels of precision.

\subsection{Survey Questionnaire}

The questionnaire used was translated to the local language of the study sites, Filipino/Tagalog for Busuanga and Bahasa for Karimunjawa. It has four sections, namely (A) socio-demographics, (B) awareness level, and (C) utilization frequency of ES, and (D) perceived threats and management strategies (modified from $[33,34]$ ). Section A profiled the name, gender, age, residency, education, and occupation of the respondents. Section $B$ and $C$ used a five-point Likert scale; awareness level was measured from 1 (not aware) to 5 (extremely aware) while utilization rate is weighed from 1 (never use) to 5 (every day). Section D measures the perceived threats and management priorities through a rating with most (1) to least (10) damaging threat and top (1) to least (7) priority, respectively. Lastly, the respondents were asked to identify from a list of stakeholders who should be managing the BCEs in their areas. 


\subsection{Data Analysis}

This study utilized descriptive statistics (i.e., frequencies, percentages, and means), comparison tests, multivariate regressions, and correlations. Descriptive statistics were used to show the respondents' socio-demographic characteristics, awareness, and utilization of BCE services, and their perceptions on threats and management of these resources. The Mann-Whitney U-test was used to evaluate if there are significant differences between the study sites in locals' awareness level and utilization frequency, and perceptions of threats and management strategies of BCEs. Moreover, multivariate regressions were utilized to evaluate the influence of respondents' socio-demographic characteristics on their awareness and utilization of BCE services. Lastly, Spearman's rank correlation coefficient ( $\rho$ ) was carried out to evaluate whether the locals' utilization patterns can be linked with their knowledge of ES [33].

\section{Results}

\subsection{Socio-Demographic Profile of the Respondents}

Table 1 shows the socio-demographics of the respondents from Busuanga $(n=98)$ and Karimunjawa $(\mathrm{n}=47)$. The respondents in Busuanga are almost equally distributed in terms of gender (male is $51.0 \%$ and female is $49.0 \%$ ) with a mean age of 44 years old. The majority (75.5\%) of the respondents is living in the neighborhood since birth (21 years or more) while others, about $11.2 \%$ are relatively new in the area (5-10 years). In terms of formal education, $51.0 \%$ of the locals have finished primary school while $30.6 \%$ have completed secondary school. About $11.2 \%$ of the respondents did not finish formal education. Moreover, in terms of occupation, salaried individuals (daily, weekly, or monthly earners) covering part-time workers, skilled workers, and government employees comprised $40.8 \%$ of the total interviewees while $23.5 \%$ are fishermen and $5.1 \%$ are farmers. The unemployed group accounts for $30.6 \%$ of the total respondents.

In contrast, a majority (87.2\%) of the respondents in Karimunjawa Island are male while only $12.8 \%$ are female respondents. More than half (51.1\%) of the respondents are in the " 41 to 50 years old" age group, with an average age of 40 years old. About $57.4 \%$ of the respondents are living on the island since birth while a few $(4.3 \%$ to $6.4 \%)$ have just resided in the area for less than 10 years. In terms of education, $66.0 \%$ of the respondents have completed secondary school, $23.4 \%$ finished primary education and about $10.6 \%$ are degree holders. The occupation of the respondents is distributed to salaried individuals $(34.0 \%)$ who include merchants, government employees, and skilled workers, fishermen $(21.3 \%)$, and housewives (6.4\%). The remaining 38.3\% did not divulge their occupation information.

\subsection{Respondents' Awareness of Blue Carbon Ecosystem Services}

The awareness level of mangrove ES in Busuanga is fairly consistent where $27.6 \%$ to $35.7 \%$ of the respondents in Busuanga are "very aware" of all the ES (i.e., source of food, coastal protection, carbon sequestration, a habitat of many organisms, cultural services) listed in the questionnaire while only $10.2 \%$ to $22.4 \%$ are not aware of these benefits (Figure 2). Meanwhile, the recognition of seagrass ES depends on the type of service. Seagrass beds as a source of food, habitat, nursery, feeding and breeding ground of many organisms, and site for cultural activities are highly recognized ("moderate" to "extremely aware") by $50.0 \%$ to $60.2 \%$ of the respondents while regulating services like coastal protection and natural buffer are poorly known ("not aware") by $42.9 \%$ to $45.9 \%$ of the sample size. Another regulating service that the locals are not so familiar with is the capacity of seagrasses to sequester and store carbon; a little over half $(54.1 \%)$ of them are aware while $45.9 \%$ are "slightly aware" to "not aware". 
Table 1. Socio-demographic profile of the respondents from Busuanga and Karimunjawa.

\begin{tabular}{|c|c|c|c|c|}
\hline \multirow{2}{*}{ Socio-Demographic Profile } & \multicolumn{2}{|c|}{ Busuanga $(\mathrm{n}=98)$} & \multicolumn{2}{|c|}{ Karimunjawa $(n=47)$} \\
\hline & Frequency & Percentage & Frequency & Percentage \\
\hline \multicolumn{5}{|l|}{ Gender } \\
\hline Male & 50 & 51.0 & 41 & 87.2 \\
\hline Female & 48 & 49.0 & 6 & 12.8 \\
\hline \multicolumn{5}{|l|}{ Age } \\
\hline $20-30$ & 20 & 20.4 & 6 & 12.8 \\
\hline $31-40$ & 22 & 22.4 & 14 & 29.8 \\
\hline $41-50$ & 23 & 23.5 & 24 & 51.1 \\
\hline $51-60$ & 19 & 19.4 & 3 & 6.4 \\
\hline 61 and above & 14 & 14.3 & 0 & 0.0 \\
\hline average age & 44 & & 40 & \\
\hline \multicolumn{5}{|l|}{ Residency } \\
\hline Less than 5 years & 0 & 0.0 & 2 & 4.3 \\
\hline 5-10 years & 11 & 11.2 & 3 & 6.4 \\
\hline $11-15$ years & 8 & 8.2 & 4 & 8.5 \\
\hline 16-20 years & 5 & 5.1 & 11 & 23.4 \\
\hline 21 years or more & 74 & 75.5 & 27 & 57.4 \\
\hline \multicolumn{5}{|l|}{ Education } \\
\hline No formal education & 11 & 11.2 & 0 & 0.0 \\
\hline Primary school & 50 & 51.0 & 11 & 23.4 \\
\hline Secondary school & 30 & 30.6 & 31 & 66.0 \\
\hline Certificate/Diploma & 2 & 2.0 & 0 & 0.0 \\
\hline Degree holder & 5 & 5.1 & 5 & 10.6 \\
\hline \multicolumn{5}{|l|}{ Occupation } \\
\hline Fisherman & 23 & 23.5 & 10 & 21.3 \\
\hline Farmer & 5 & 5.1 & 0 & 0.0 \\
\hline Salaried individual & 40 & 40.8 & 16 & 34.0 \\
\hline Unemployed & 30 & 30.6 & 3 & 6.4 \\
\hline Did not answer & & & 18 & 38.3 \\
\hline
\end{tabular}

Meanwhile, in Karimunjawa, trends on the awareness level of mangroves and seagrasses' ES are the same (Figure 2). About 37.0\% to $45.7 \%$ (mangroves) and 30.4\% to 35.6\% (seagrasses) of the respondents are "extremely aware" of supporting (serves a nursery, feeding, and breeding area), regulating (coastal protection and natural buffer), and cultural (recreational and educational) services. Also, 32.6\% to $37.0 \%$ of the respondents are "very aware" that BCEs serve as habitats for many organisms and have water filtration functions. Interestingly, almost half ( $43.5 \%$ to $45.7 \%$ ) of the respondents are "not aware" that these ecosystems are a great source of food. Moreover, similar patterns with Busuanga were observed in Karimunjawa for blue carbon functions, where $50.0 \%$ to $52.2 \%$ of the respondents are "moderate" to "extremely aware" while $47.8 \%$ to $50.0 \%$ are "slightly" to "not aware".

The Mann-Whitney $U$ test was used to compare the awareness level between the two study sites (Table 2). Based on the analysis, the respondents in Karimunjawa have higher recognitions ( $\mathrm{M}=3.7$ to 4.0, "very aware") of supporting (nursery, feeding, breeding area), regulating (coastal protection and natural buffer), and cultural (recreational and educational) services of mangroves than Busuanga's awareness level, which is "moderately aware" ( $\mathrm{M}=2.9$ to 3.3). Conversely, provisioning services of mangroves (source of food) are perceived higher ( $\mathrm{M}=3.4$, "moderately aware") in Busuanga compared to Karimunjawa $(\mathrm{M}=2.6$, "slightly aware"). For seagrass awareness, relatively similar trends with mangrove awareness were observed. Respondents in Karimunjawa have higher perceptions, "moderate" to "very aware" that seagrasses can serve as a nursery, feeding, and breeding ground $(M=3.7)$, habitat for many organisms $(M=3.7)$, protect coastal areas $(M=3.4)$, and act as a natural buffer $(\mathrm{M}=3.5)$ compared to Busuanga's "slight" to "moderate" awareness $(\mathrm{M}=2.4$ to 3.0). 


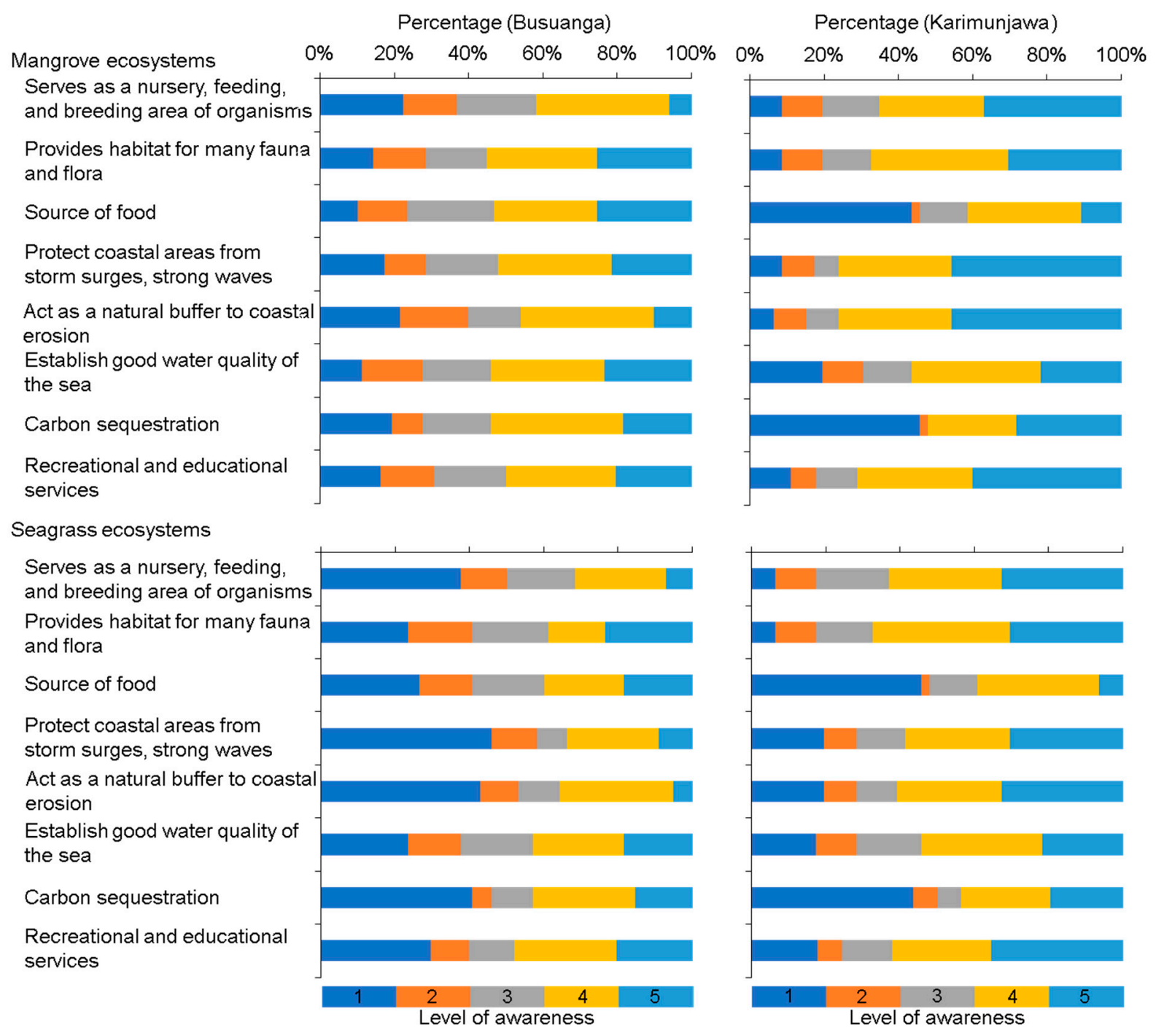

Figure 2. Awareness level of Busuanga $(n=98)$ and Karimunjawa $(n=47)$ respondents of BCE services. The awareness level is based on a five-point Likert scale ( 1 = not aware, 2 = slightly aware, $3=$ moderately aware, $4=$ very aware, $5=$ extremely aware).

\subsection{Respondents' Utilization of Blue Carbon Ecosystem Services}

Generally, the provisioning and cultural services of BCEs are poorly utilized by the residents in both study sites (Figure 3). In Busuanga, 27.6\% of the respondents have collected fishes and other seafood in mangrove areas at least once a week and $23.5 \%$ have done it once a month while the majority (33.7\%) have never done it. About $25.5 \%$ of the respondents have collected seafood as an income source once a week, although a bigger portion (48.0\%) have never utilized mangroves as an income source. Moreover, $75.5 \%$ of the sample size has never harvested mangroves as firewood materials. In terms of cultural services, only $22.4 \%$ of them have visited this habitat once a month for bird or bat watching while $75.5 \%$ have never utilized it for other recreational activities like paddling. Roughly $90.8 \%$ of the locals have never accessed the mangrove areas for research or educational purposes. Accessing seagrass meadows for its provisioning and cultural services has been observed to be very low, $53.1 \%$ to $92.9 \%$ of the respondents in Busuanga. 
Table 2. Comparison of respondents' awareness level between Busuanga and Karimunjawa.

\begin{tabular}{|c|c|c|c|c|c|}
\hline & \multirow[b]{2}{*}{ Ecosystem Services } & \multicolumn{2}{|c|}{ Busuanga $(n=98)$} & \multicolumn{2}{|c|}{ Karimunjawa $(n=47)$} \\
\hline & & $\begin{array}{l}\text { Weighted } \\
\text { Mean a }^{\text {a }}\end{array}$ & Description & $\begin{array}{l}\text { Weighted } \\
\text { Mean }^{\text {a }}\end{array}$ & Description \\
\hline \multirow{8}{*}{ 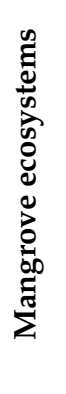 } & $\begin{array}{c}\text { Serves as a nursery, feeding, and breeding area } \\
\text { of organisms }\end{array}$ & 2.9 * & moderately aware & $3.7 *$ & very aware \\
\hline & Provides habitat for many fauna and flora & 3.4 & moderately aware & 3.7 & very aware \\
\hline & Source of food & $3.4^{*}$ & moderately aware & $2.6^{*}$ & slightly aware \\
\hline & $\begin{array}{c}\text { Protect coastal areas from storm surges, strong } \\
\text { waves }\end{array}$ & 3.3 * & moderately aware & $4.0^{*}$ & very aware \\
\hline & Act as a natural buffer to coastal erosion & 2.9 * & moderately aware & $4.0 *$ & very aware \\
\hline & Establish good water quality of the sea & 3.4 & moderately aware & 3.3 & moderately aware \\
\hline & Carbon sequestration & 3.3 & moderately aware & 2.9 & moderately aware \\
\hline & Recreational and educational services & $3.2 *$ & moderately aware & $3.8^{*}$ & very aware \\
\hline \multirow{8}{*}{ 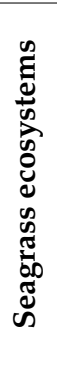 } & $\begin{array}{c}\text { Serves as a nursery, feeding, and breeding area } \\
\text { of organisms }\end{array}$ & $2.5^{*}$ & slightly aware & $3.7 *$ & very aware \\
\hline & Provides habitat for many fauna and flora & $3.0 *$ & moderately aware & 3.7 * & very aware \\
\hline & Source of food & $2.9 * *$ & moderately aware & $2.5^{* *}$ & slightly aware \\
\hline & $\begin{array}{c}\text { Protect coastal areas from storm surges, strong } \\
\text { waves }\end{array}$ & $2.4^{*}$ & slightly aware & $3.4^{*}$ & moderately aware \\
\hline & Act as a natural buffer to coastal erosion & $2.4 *$ & slightly aware & $3.5^{*}$ & very aware \\
\hline & Establish good water quality of the sea & 3.0 & moderately aware & 3.3 & moderately aware \\
\hline & Carbon sequestration & 2.7 & moderately aware & 2.7 & moderately aware \\
\hline & Recreational and educational services & 3.0 & moderately aware & 3.6 & very aware \\
\hline
\end{tabular}

Notes: a Measured on a five-point Likert scale ranging from "not aware" (1) to "extremely aware" (5). Values with * $(p<0.05),{ }^{* *}(p<0.10)$ are statistically different based on the Mann-Whitney U test.

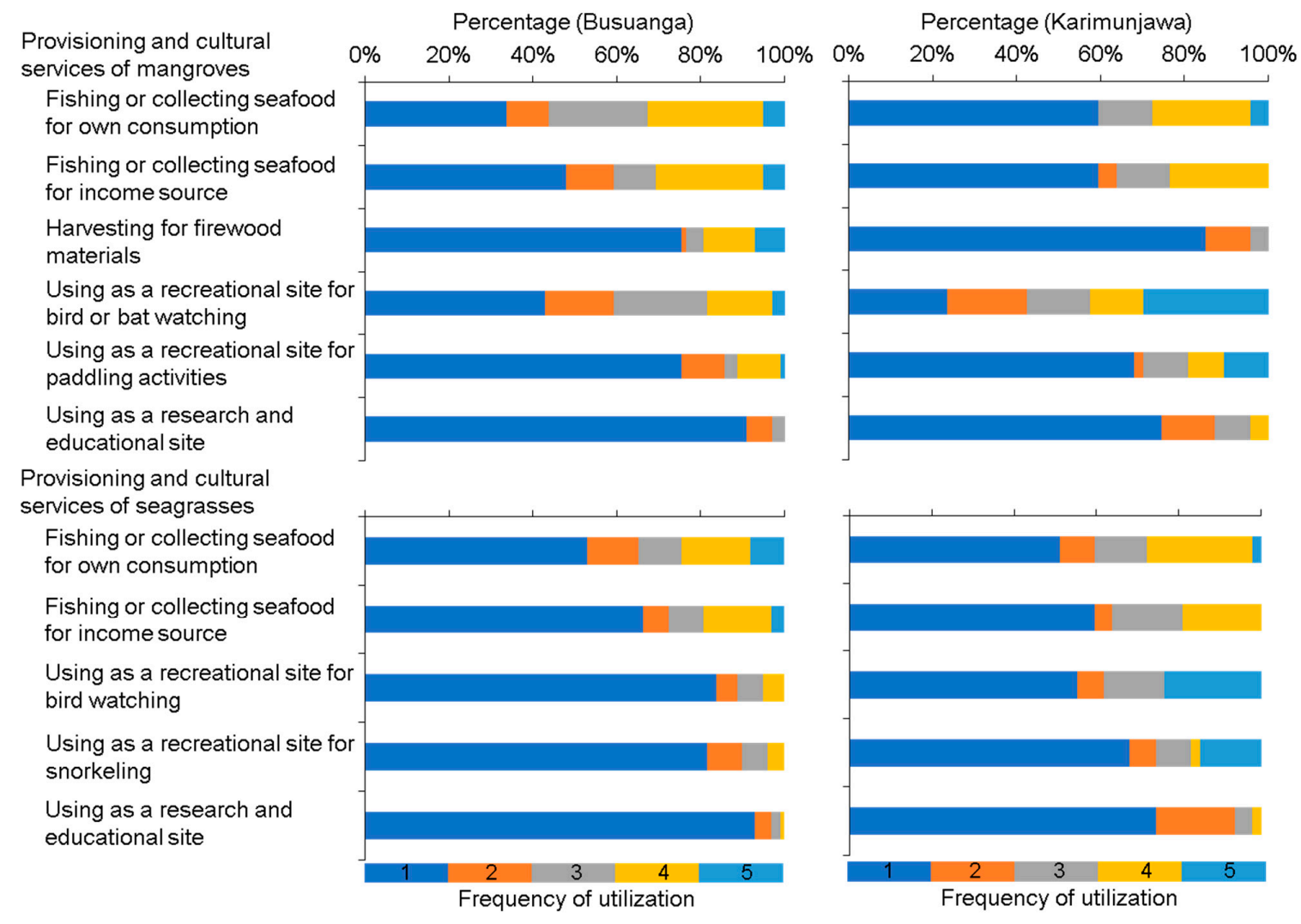

Figure 3. Utilization frequency of Busuanga $(n=98)$ and Karimunjawa $(n=47)$ respondents of provisioning and cultural services of BCEs. The frequency is based on a five-point Likert scale ( 1 = never use, 2 = once a year, $3=$ once a month, $4=$ once a week, 5 = every day). 
Similar trends were observed in Karimunjawa, $23.4 \%$ of the respondents have collected fish and other seafood in mangroves once a week for their own consumption and income source while more than half (59.6\%) have never utilized it (Figure 3). Harvesting mangroves for firewood materials was never done by $85.1 \%$ of the respondents while a few of them $(10.6 \%)$ have harvested them at least once a year. For cultural services, bird or bat watching in mangrove areas is done every day by $29.8 \%$ of the sample size, $12.8 \%$ for once a week, $14.9 \%$ for once a month, and $19.1 \%$ for once a year while $23.4 \%$ have never done it. Meanwhile, $68.1 \%$ and $74.5 \%$ of the respondents have never accessed this habitat for paddling and educational purposes, respectively. Moreover, seagrass utilization is also low, more than half (51.1\% to $74.5 \%$ ) of the sample size has never accessed this ecosystem to collect seafood, as livelihood options, and as recreational sites. However, it is noteworthy that at least $25.5 \%$ of the respondents have gleaned in seagrass beds once a week and $23.4 \%$ of the respondents have observed birds in this habitat every day.

Although both utilization patterns in the study sites are relatively low, the comparison of weighted means through the Mann-Whitney $U$ test showed significant differences in the results (Table 3). Higher values were obtained in Busuanga for using mangrove to collect food $(\mathrm{M}=2.6)$ and firewood materials $(\mathrm{M}=1.7)$ while Karimunjawa has a weighted mean of 2.1 and 1.2 for fishing (own consumption) and harvesting for firewood materials, respectively. Conversely, accessing seagrass beds for their cultural benefits is higher in Karimunjawa than in Busuanga. For instance, using this habitat as a site for bird watching and snorkeling activities are done at least once a year $(\mathrm{M}=2.3$ and $\mathrm{M}=1.9$, correspondingly) in the former while the respondents in the latter never used it for bird watching $(\mathrm{M}=1.3)$ and snorkeling $(\mathrm{M}=1.3)$.

Table 3. Comparison of respondents' utilization frequency of provisioning and cultural services between Busuanga and Karimunjawa.

\begin{tabular}{|c|c|c|c|c|c|}
\hline & \multirow{2}{*}{ Provisioning and Cultural Services } & \multicolumn{2}{|c|}{ Busuanga $(n=98)$} & \multicolumn{2}{|c|}{ Karimunjawa $(n=47)$} \\
\hline & & Weighted Mean ${ }^{a}$ & Description & Weighted Mean a & Description \\
\hline \multirow{6}{*}{ 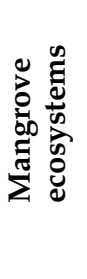 } & Fishing for own consumption & $2.6 *$ & once a year & $2.1 *$ & once a year \\
\hline & Fishing for income source & 2.3 & once a year & 2.0 & once a year \\
\hline & Harvesting for firewood materials & $1.7^{* *}$ & never use & $1.2 * *$ & never use \\
\hline & $\begin{array}{c}\text { Using as a recreational site (bird or bat } \\
\text { watching) }\end{array}$ & 2.2 & once a year & 3.1 & once a month \\
\hline & Using as a recreational site (paddling) & 1.5 & never use & 1.9 & once a year \\
\hline & Used as a research or educational site & 1.1 & never use & 1.4 & never use \\
\hline \multirow{5}{*}{ 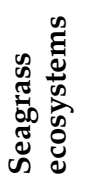 } & Fishing for own consumption & 2.1 & once a year & 2.2 & once a year \\
\hline & Fishing for income source & 1.8 & once a year & 2.0 & once a year \\
\hline & Using as a recreational site (bird watching) & $1.3^{*}$ & never use & $2.3^{*}$ & once a year \\
\hline & Using as a recreational site (snorkeling) & $1.3^{*}$ & never use & 1.9 * & once a year \\
\hline & Used as a research or educational site & $1.1 *$ & never use & 1.3 * & never use \\
\hline
\end{tabular}

Notes: ${ }^{a}$ Measured on a five-point Likert scale ( $1=$ never use, $2=$ once a year, $3=$ once a month, $4=$ once a week, $5=$ everyday). Values with $*(p<0.05),{ }^{* *}(p<0.10)$ are statistically different based on the Mann-Whitney U test.

\subsection{Perceived Threats to Blue Carbon Ecosystems}

The residents were asked to rank the threats based on their perceptions from most (1) to least (10) damaging threats (Table 4). Almost half (48.5\%) of the respondents of Busuanga have identified natural disasters (i.e., typhoons, storm surges) to be the most (1st) concerning threat to mangroves whereas conversion to fishponds is perceived by $64.9 \%$ to be the least (10th) threat. Illegal cutting of mangroves (18.6\%) came second in the rank along with pollution from domestic wastes $(34.7 \%)$. Other perceived anthropogenic threats to mangroves like charcoal making, increasing population, informal settlers, building coastal infrastructures, conversion to nipa and coconut plantation, and conversion to residential areas ranked fourth $(34.7 \%)$, fifth $(30.6 \%)$, sixth $(21.4 \%)$, seventh $(26.8 \%)$, eighth $(35.7 \%)$, 
and ninth (50.5\%) places, respectively. Conversely, perceived threats in Karimunjawa are ranked differently (Table 4). For instance, $28.3 \%$ of the respondents of Karimunjawa have recognized natural disasters to be the least (10th) damaging threat to mangroves opposite to Busuanga's results. The difference is statistically significant $(p<0.05)$ based on the MannWhitney $\mathrm{U}$ test. Other significant differences on perceived threats observed in Karimunjawa include charcoal making (3rd, 21.7\%), building infrastructures (third, 17.4\%), conversion to fishponds (fifth, $19.6 \%$ ), conversion to residential areas (sixth, $23.9 \%$ ), conversion to palm tree plantation (eighth, 21.7\%), and increasing population (ninth, $28.3 \%$ ).

Table 4. Perceived threats to blue carbon ecosystems.

\begin{tabular}{|c|c|c|c|c|c|c|}
\hline \multirow{2}{*}{$\begin{array}{c}\text { Perceived Threats } \\
\text { Mangrove Ecosystems }\end{array}$} & \multicolumn{3}{|c|}{ Busuanga } & \multicolumn{3}{|c|}{ Karimunjawa } \\
\hline & Mode $^{a b}$ & Percentage & $\begin{array}{l}\text { Weighted } \\
\text { Mean b }^{\text {b }}\end{array}$ & Mode $^{\text {ab }}$ & Percentage & $\begin{array}{c}\text { Weighted } \\
\text { Mean b }\end{array}$ \\
\hline Natural disasters & 1 & 48.5 & $3.2 *$ & 10 & 28.3 & $6.6^{*}$ \\
\hline Pollution (domestic wastes) & 2 & 34.7 & 2.8 & 2 & 23.9 & 3.7 \\
\hline Informal settlers & 6 & 21.4 & 5.1 & 6 & 20.0 & 4.9 \\
\hline Increasing population & 5 & 30.6 & $5.7 *$ & 9 & 28.3 & $6.9 *$ \\
\hline Charcoal making & 4 & 34.7 & $3.6^{*}$ & 3 & 21.7 & $5.5 *$ \\
\hline $\begin{array}{l}\text { Conversion to nipa and coconut/palm tree } \\
\text { plantation }\end{array}$ & 8 & 35.7 & $7.2 *$ & 8 & 21.7 & $5.4^{*}$ \\
\hline Mangrove cutting & 2 & 18.6 & 3.9 & 1 & 26.1 & 4.7 \\
\hline Building infrastructures in coastal areas & 7 & 26.8 & $6.5^{*}$ & 3 & 17.4 & $5.5^{*}$ \\
\hline Conversion to residential areas & 9 & 50.5 & 7.7 * & 6 & 23.9 & $5.6 *$ \\
\hline Conversion to fishponds & 10 & 64.9 & 8.9 * & 5 & 19.6 & $5.1 *$ \\
\hline \multicolumn{7}{|l|}{ Seagrass ecosystems } \\
\hline Natural disasters & 1 & 39.8 & $3.3^{*}$ & 10 & 28.3 & $5.9 *$ \\
\hline Pollution (domestic wastes) & 1 & 43.9 & 2.1 * & 1 & 28.3 & $4.1^{*}$ \\
\hline Increasing population & 3 & 22.4 & $5.5^{*}$ & 6 & 21.7 & $6.7^{*}$ \\
\hline Building infrastructures in coastal areas & 4 & 17.3 & 5.7 & 6 & 21.7 & 5.0 \\
\hline Mangrove planting on seagrass beds & 4 & 18.4 & 5.4 & 8 & 17.4 & 5.8 \\
\hline Sand mining & 6 & 16.3 & 5.4 & 5 & 23.9 & 5.2 \\
\hline Unregulated gleaning & 6 & 21.4 & $6.6^{*}$ & 2 & 19.6 & $5.3 *$ \\
\hline Siltation & 6 & 17.3 & 5.5 & 2 & 17.4 & 5.2 \\
\hline Beach reclamation & 9 & 33.7 & $7.4^{*}$ & 4 & 19.6 & $4.6^{*}$ \\
\hline Increasing sea surface temperature & 10 & 52.0 & $8.4^{*}$ & 10 & 23.9 & $6.0 *$ \\
\hline
\end{tabular}

Notes: ${ }^{\text {a }}$ Most frequently occurring response, ${ }^{\mathrm{b}}$ measured from most (1) to least (10) damaging threats. ${ }^{*}$ difference is statistically significant at $p<0.05$ based on the Mann-Whitney $\mathrm{U}$ test.

Seagrass ecosystems are also highly vulnerable to natural and anthropogenic threats. Pollution from domestic wastes ranked first in the list of damaging threats in both study sites (Table 4). Similar to mangroves' threats, natural disasters occurring in Busuanga are also perceived by $39.8 \%$ of the sample size to be at the top list of threats whereas $28.3 \%$ of the respondents of Karimunjawa ranked it at the bottom of the list along with increasing sea surface temperature $(23.9 \%)$. Moreover, mangrove planting in seagrass beds $(18.4 \%)$ and building infrastructures in coastal areas $(17.3 \%)$ in Busuanga tied in fourth place followed by sand mining $(16.3 \%)$, unregulated gleaning $(21.4 \%)$, and siltation $(17.3 \%)$ all in sixth place. Beach reclamation and increasing sea surface temperature are perceived to be the least threats, occupying the 9th (33.7\%) and 10th (52.0\%) places, respectively. Meanwhile, in Karimunjawa, unregulated gleaning and beach reclamation are ranked significantly different $(p<0.05)$ taking the second $(19.6 \%)$ and fourth (19.6) places, correspondingly.

\subsection{Perceived Management Strategies to Blue Carbon Ecosystems}

The respondents rated the strategies for BCEs management from the top (1) to least (7) priority measures. As shown in Table 5, 30.9\% and $23.4 \%$ of the respondents in Busuanga have recognized "Organization strengthening and capacity development" and "Coastal and fisheries law enforcement" as the top strategies that need to be prioritized whereas 
23.4\% of the sample size in Karimunjawa acknowledged "Habitat management and marine sanctuaries" to be highly prioritized. Meanwhile, the least important strategies as perceived by the residents are "Information and educational campaigns" (29.0\%) and "Coastal zoning" $(27.7 \%)$ in Busuanga and "Coastal Zoning" (21.3\%) in Karimunjawa.

Table 5. Perceived blue carbon ecosystem management strategies.

\begin{tabular}{|c|c|c|c|c|c|c|}
\hline \multirow[b]{2}{*}{ Perceived Management Strategies } & \multicolumn{3}{|c|}{ Busuanga } & \multicolumn{3}{|c|}{ Karimunjawa } \\
\hline & Mode $^{a b}$ & Percentage & $\begin{array}{l}\text { Weighted } \\
\text { Mean }^{b}\end{array}$ & Mode $^{a b}$ & Percentage & $\begin{array}{l}\text { Weighted } \\
\text { Mean b }\end{array}$ \\
\hline $\begin{array}{c}\text { Organization strengthening and capacity } \\
\text { development }\end{array}$ & 1 & 30.9 & $2.8^{*}$ & 5 & 23.4 & $4.5^{*}$ \\
\hline Coastal and Fisheries Law Enforcement & 1 & 23.4 & 3.3 & 4 & 25.5 & 3.5 \\
\hline Fisheries Management & 4 & 19.1 & 3.5 & 2 & 19.1 & 3.8 \\
\hline Habitat management and marine sanctuaries & 3 & 22.3 & $4.1 *$ & 1 & 23.4 & $3.5 *$ \\
\hline Enterprise, livelihood, and tourism development & 5 & 23.2 & 4.3 & 5 & 23.4 & 4.1 \\
\hline Information and educational campaigns & 6 & 29.0 & $4.8^{*}$ & 2 & 21.3 & $4.1^{*}$ \\
\hline Coastal zoning & 6 & 27.7 & 4.1 & 7 & 21.3 & 4.6 \\
\hline
\end{tabular}

Notes: a Most frequently occurring response, ${ }^{\mathrm{b}}$ measured from the top (1) to least (7) priority management strategies. ${ }^{*}$ difference is statistically significant at $p<0.05$ based on the Mann-Whitney $\mathrm{U}$ test.

Moreover, residents were asked for their perceptions of who should be in charge of managing their BCEs (Figure 4). More than half (51.6\% to $52.6 \%$ ) of the respondents in Busuanga perceived that local residents should take the lead in the management of their mangroves and seagrasses while $21.7 \%$ to $23.9 \%$ of the sample size in Karimunjawa recognized that management should be a collective effort among local residents, local government, central government, NGOs and private sectors. Management by local government units is also acknowledged by $20.0 \%$ to $21.1 \%$ of the residents in Busuanga and $10.9 \%$ to $13.0 \%$ in Karimunjawa. A combined effort between local residents and local government units received fair recognition, $13.7 \%$ to $15.8 \%$, in Busuanga and $15.2 \%$ in Karimunjawa. NGO-led managements are perceived by a small fraction, about $2.2 \%$ of the sample size in Karimunjawa whereas no recognition was recorded in Busuanga.

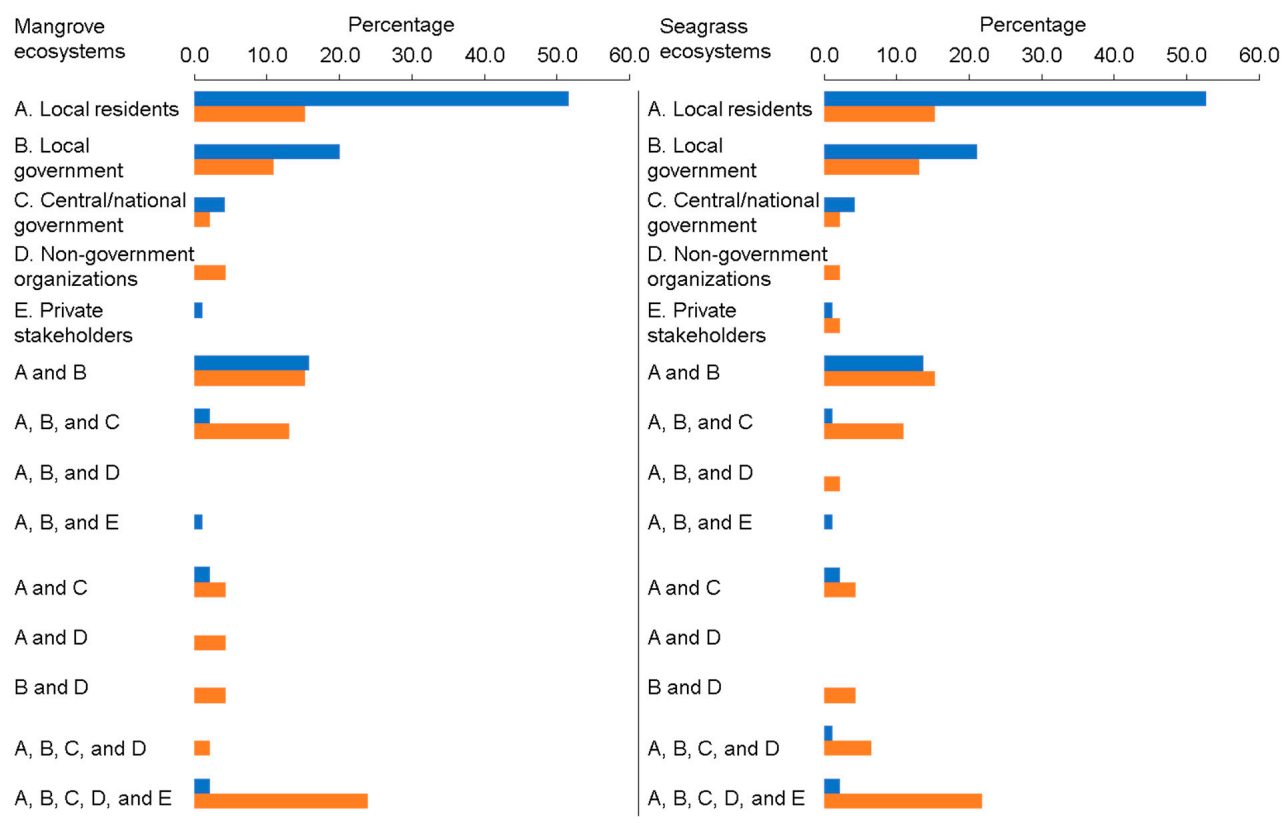

Figure 4. Perceived stakeholders to manage the blue carbon ecosystems. Blue bars represent Busuanga $(n=98)$ while orange bars reflect Karimunjawa $(n=47)$ respondents. 


\section{Discussions}

\subsection{Awareness and Utilization of Blue Carbon Ecosystems}

The residents of Busuanga have a high recognition of mangroves because of their tangible benefits. Field observations and oral accounts documented that locals collect fish and shells in mangrove areas when their financial capacity to buy food is limited. This scenario is very common among coastal communities in the Philippines. Some locals are getting paid for assisting recreational activities such as firefly watching and paddling in mangrove areas. Moreover, coastal residents have first-hand experience with the protection services of mangroves when the super typhoon Haiyan hit the country in 2013. Ref. [33] have documented that mangrove services are highly recognized by the people when they are directly benefited by them; the more services they can get or observe, the higher they value the ecosystem. As for seagrass awareness, provisioning services are well acknowledged by the locals compared to other services (i.e., regulating, cultural). Unlike mangroves, seagrass ecosystem services are not well streamlined in coastal programs or often grouped with other ecosystems because the priorities for research and development activities are usually directed towards coastal resources with immediate economic impacts [34,55]. However, C3 Philippines, an NGO, is changing this trend. This group has already conducted several seagrass awareness campaigns (including blue carbon functions) on the island as part of their thrusts on the Dugong conservation program (program coordinator of C3 Philippines, personal communication, 19 July 2019).

The utilization frequency of BCE services in Busuanga is generally low despite residents' proximity to these resources (see Figure 3). Using correlation and multiple regressions, awareness level and sociodemographic characteristics of the locals were explored to determine whether these have an influence or none on their utilization behaviors (see Supplementary Materials). This study shows that the effect of social profile on the local's utilization behavior is inconclusive. As pointed out by [56], socio-demographics as predictor variables do not always influence their behavior. However, to some degree, the occupation of the residents influences their utilization behavior (as hypothesized); fishers are more active in using the BCEs services meanwhile others (i.e., farmers, employed individuals) are less active. Fishing in BCEs, though, is low in Busuanga since they utilize coral reefs more [57]. Harvesting mangroves for charcoal-making has reduced due to strict implementation of local ordinances and the establishment of marine protected areas on the island [57]. Moreover, cultural services offered by the BCEs are not used since most of the tourism-related activities on the island feature other ecosystems like coral reefs, beaches, and small islands.

The awareness level of BCE services in Karimunjawa reflects an overall low trend that agrees with previous perception studies on the island (i.e., [58,59]). Provisioning benefits are poorly received while cultural functions of BCEs are well perceived (see Figure 2). Regulating services like the blue carbon functions are generally unrecognized, while coastal protection and natural buffer services are acknowledged by the locals. To date, there are now different blue carbon opportunities in Indonesia [29], however, blue carbon related works are mainly focused on the carbon potential of BCEs (i.e., [60]) rather than on BCE awareness and capacity building among coastal communities.

Looking at the possible factors affecting their perceptions, the occupation of the locals is negatively associated with their awareness and utilization behaviors. Based on the 2017 population of Karimunjawa, fishers comprise $47.0 \%$ of the residents [45] thus, it is expected to document high utilization frequency (positive correlation). However, this study shows low utilization frequency (negative correlation); $59.6 \%$ to $68.1 \%$ of the locals do not perform fishing/gleaning activities. This may be due to the smaller number of fishers $(21.3 \%)$ in the respondents and more $(34.0 \%)$ salaried individuals. Accessibility to BCEs could potentially influence resident's usage rate [58]; however, despite the proximity of the respondents to BCEs, utilization yields are still low. This is because most of the fishers on the island are pelagic fishers [45]. Another factor that could influence their utilization is the level of awareness. Similar to Busuanga, the awareness and utilization 
in Karimunjawa correlate with each other. Residents who utilized the services (i.e., food source) are typically those who only recognized the benefits of BCEs. The work of [59] on the island also captured fewer fishing activities in mangroves because of their low awareness while gleaning activities in seagrass beds depend on the awareness of the abundance of associated organisms [58]. Interestingly, activities related to cultural activities are also low (see Figure 3) despite Karimunjawa becoming a popular tourism site [59].

\subsection{Threats to Blue Carbon Ecosystems}

Natural disturbances like typhoons resulting in strong waves and storm surges are perceived to be the most damaging threat to BCEs in Busuanga (see Table 4). The residents highly recognized natural calamities to destroy BCEs since they have personal experiences and observations. For example, when the super typhoon Haiyan devastated the Philippines in 2013, it caused significant damage to BCEs in the country $[61,62]$. During the conduct of household surveys, many residents recalled and shared their observations on how the super typhoon destroyed the mangroves and seagrasses. Similar findings were also documented from the residents in Eastern Samar where the super typhoon first hit the country [33].

Pollution from domestic wastes was also recognized to be one of the top concerning threats. Photo documents clearly showed solid wastes in coastal areas where communities live. The lack of discipline and effective solid waste management systems are common factors that propagate increasing pollution pressure to BCEs. Other concerning threats to mangroves include illegal harvesting for firewood and charcoal-making. This problem has been a consistent challenge to address since local communities have direct access to mangrove forests [1]; however, a recent survey in the locality has shown a decline in illegal activities due to the presence of local ordinances and national policies (i.e., [33]). Conversion to fishponds was identified as the least concerning threat since there are no converted aquaculture ponds in Busuanga. This is noteworthy since conversion to fishponds was one of the main causes of rapid mangrove degradation in the country in the early years [1]. Current programs and policies (i.e., Coastal Resource Management Programs, Revised Forestry Code of the Philippines (Presidential Decree No. 705)) at the local and national level have reduced these activities. Meanwhile, perceived threats specific to seagrasses include mangrove planting on seagrass beds, unregulated gleaning, and siltation. These pressures from human activities could result in a cascading effect in the whole coastal ecosystem. For instance, unregulated gleaning could result in biodiversity loss [63]. In the Philippines, cases of seagrass and associated organisms' decline were perceived and attributed to these human-induced stressors [55].

Conversely, the effect of natural disturbances on BCEs in Karimunjawa is perceived to be the least concerning threat as reflected in the results (see Table 4). Unlike the Philippines, the average number of tropical cyclones in Indonesia is seven (7) per year or about 9\% of the average number of cyclones globally, because, in principle, tropical cyclones do not cross the country as they will always move away from the equator [64]. The lack of personal experiences and observations on the effect of natural disturbances on BCEs likely influenced residents' perceptions. In the perception study conducted by [59] in Karimunjawa, there are no questions about the effects of natural threats, as they are mostly human-derived. Their study showed that mangrove degradation in the island is correlated with human-derived disturbances; mangrove logging has the strongest correlation $(p<0.01)$ while the development of offshore inns (guesthouses) has the weakest correlation $(p<0.05)$. Conformingly, the results of this study also identified anthropogenic threats (i.e., mangrove cutting, pollution) as the top perceived causes of mangrove degradation. The recognition of human-induced threats to mangroves has been long supported by quantitative researches (i.e., $[65,66]$ ) and has been observed not just in Karimunjawa but also in other areas in Indonesia. For instance, mangrove losses due to conversion into oil palm plantation and other land uses were observed in the islands of Mentawau (West Sumatra), Lankat (North Sumatra), Bawal (West Kalimantan), Seram (Maluku), Bangka Belitung, and Enggano 
Bengkulu [67]. The results of this study and previous researches (i.e., [59,68]) indicate that mangroves in Indonesia are still threatened by manmade activities despite an increase in management strategies (i.e., $[66,69,70])$.

Seagrasses in Karimunjawa are also perceived to be most threatened by anthropogenic disturbances (i.e., pollution, unregulated gleaning). There are not many published studies on seagrass ecosystems in Karimunjawa, however, seagrasses in small islands in Indonesia are generally highly vulnerable to human-induced activities [58]. Destructive fishing methods (push nets and trawls), coastal constructions, and sedimentation from coastal development are also among the top activities in Indonesia that damage the seagrasses [16]. Household wastes also affect the seagrasses; for example, in Spermonde Archipelago in South Sulawesi, seagrasses' health is influenced by the nutrient loading, turbidity, and total suspended solids coming from domestic solid and liquid wastes [71]. The results of this study conform with the survey conducted by [72] with seagrass experts in Indonesia such that current and future threats are mostly human-derived activities such as coastal development, sedimentation, poor water quality, seaweed farming, overexploitation of herbivores, and coastal erosion.

\subsection{Management Strategies of Blue Carbon Ecosystems}

In recent years, marine ecosystems in Busuanga have improved due to the presence of regulatory boards (i.e., PCSD), local authorities (i.e., MAO), and NGOs (i.e., C3 Philippines). There is also the creation of Fisheries and Aquatic Resources Management Councils (FARMCs) and different POs (i.e., fishers' association) which empowers communities to join management-related activities. However, despite the presence of different organizations, the residents prefer that organizational strengthening and capacity development and law enforcement should still be prioritized first in the list of management strategies (see Table 5). These perceptions agree with findings of [73] that community-based management has not been successful because communities lack self-sufficiency and their participation is merely rhetorical. There is a need to strengthen and capacitate communities in coastal management. Previous studies have documented that the ecosystems' (i.e., mangroves) conditions in Busuanga Island have improved through collaborative protective management with the POs [74] and a stronger presence of NGOs in the communities [73]. To further strengthen management strategies, FARMCs and POs have encouraged local constituents and members to actively participate in management-related activities such as coastal clean-up and mangrove planting. The positive reception of the locals in these initiatives could explain why around $50 \%$ of the respondents said locals should manage their BCEs (see Figure 4). Other areas in the Philippines have had practices where locals are active stakeholders in the management of BCEs [26].

The continued degradation of coastal resources on the island has also been linked to the weak presence and enforcement of habitat protection and management interventions [49]. Field observations and stories from the locals revealed that some illegal activities like mangrove cutting are still ongoing partly because of weak law enforcement. Ref. [44] documented the lack of strict implementation and law enforcement in their coastal governance and management system. There is also a concern for the ambiguity and overlapping roles of government organizations and NGOs, which can cause frustration and even conflict in the community [73]. Thus, it is important to establish different policies and plans for organizations in the community. For the lowest priority strategies, residents ranked information and educational campaigns and coastal zoning at the bottom (see Table 5) since these programs are already implemented on the island. Awareness campaigns are done by $\mathrm{C} 3$ Philippines, an NGO, for coastal communities around the island (C3 program coordinator, personal communications, 19 July 2020) while PCSD regulates the use of coastal zone [44].

The governance system in Karimunjawa has an overall weak performance in terms of addressing conflicts and meeting objectives to protect fishery resources from unsustainable and destructive practices [48]. The lack of stronger resource management on the island 
is reflected in the perceptions where locals recognized the need to prioritize the marine sanctuaries, habitat, and fisheries management (see Table 5). Almost half $(47 \%)$ of the population on the island are fishers [45]; therefore, it is expected that residents prefer to prioritize management strategies affecting their livelihoods. Communities that have a high dependency on marine resources are generally more supportive of strategies related to fisheries management. There is also a need to carry out more information and educational campaigns to increase their awareness of BCEs. Although the results of this study show relatively high awareness of the benefits, the overall assessment reflects a lack of knowledge, which could result in weak participation in conservation activities (see Figure 4). For instance, the communities have relatively low motivation for participating in managementrelated activities because of poor awareness about the advantages of mangroves and the impacts of their degradation [59]. In addition, communities are not interested in joining the conservation activities due to a lack of direct economic incentives [75]. Moreover, the communities prefer that all stakeholders (i.e., residents, government, private sectors) should participate in managing their coastal resources (see Figure 4). This collaborative management approach on the island has long been implemented since 2007 [48]. In Indonesia, there are only a few cases of marine resource management that are co-managed by communities and the government [76]. The governance system should respect the customary knowledge, rules, decision-making process of the local communities to get the support of the communities [48]. Meanwhile, the lowest priority is coastal zoning. There is already a strict zonation policy that is being implemented and followed on the island [66] thus, the residents placed this strategy at the bottom of the list (see Table 5). The zonation of the island allows regulatory controls on different uses outlined in the management plan, like issuing permits to harvest some natural resources sustainably and conduct activities related to education and research purposes.

\section{Implications to Management of Blue Carbon Ecosystems in the Coral Triangle Region}

Despite the gaining momentum of the "blue carbon" discourse and collaborative action in the international and national arenas, there is still a lot of work to be done at the local level, particularly where local governments and implementers are the ones interacting with these ecosystems. This study presents an opportunity to level off BCEs perceptions at the local level in the CTR, particularly in the countries of Indonesia and the Philippines. People's awareness level, utilization rates, and perceived threats and management strategies are used as proxies to determine the familiarity of coastal communities with BCEs. The results of this work show that local communities are aware of the services they can get from BCEs. However, their awareness depends entirely on the type of benefit they directly receive. For instance, provisioning services (i.e., food source) is fairly acknowledged in Busuanga while poorly recognized in Karimunjawa. Personal experiences of the residents also greatly influence their perception of the BCEs.

Factors affecting their perceptions were explored in this study as well. Although the effect of socio-demographics on awareness and utilization in this work is inconclusive, it is important to consider these factors when looking at the role of communities in coastal management. Not only the quantitative aspects of the effect but qualitative aspects can be analyzed applying text mining methods to the interview results of locals $[77,78]$. The willingness of the locals to actively participate in management-related activities depends on their awareness level. In Busuanga, where locals have high regard for BCEs, they are willing to manage them. In contrast, residents in Karimunjawa prefer their local government or a multisectoral management scheme since they have low comprehension of the BCE services. This observation is a useful indicator in strategizing advocacy campaigns and the levels of engagement of local stakeholders in the CTR. It is noteworthy that engaging local communities in ecosystem service assessments helps define their role in multi-governance of the environments as well as the importance of ES and the factors that influence social preferences and trade-offs related to land-use change and decision-making [38]. 
Another implication of this study on BCEs in the CTR is the perceived threats. To enable the sustainable management of these resources in the region, threats that destroy them should be identified first. Damages caused by natural disturbances are hard to address but restoration and rehabilitation of BCEs after a catastrophic event can be done $[1,55]$ while anthropogenic threats are the ones that can be prevented and addressed directly. This study documented that human activities (i.e., cutting, coastal development) are concerning threats to BCEs in Busuanga and Karimunjawa. Through the locals' responses, different stakeholders can have an opportunity to address present and future threats at local scales where management strategies are often weak compared to the national level. Reducing or prohibiting these activities can ensure the proliferation of BCEs in the CTR.

This perception study, particularly on the section where locals were asked to prioritize management efforts, to some extent, served as (a) a feedback mechanism on the impact of prior and/or existing BCE management activities; and (b) an assessment tool that helps identify the gaps of the management plans and programs for the two countries. First, it was made evident that in both sites, the least prioritized management actions are the ones that are already being strongly and widely, if not effectively, implemented such as information and educational campaigns in Busuanga and coastal zoning in Karimunjawa. Second, the locals' responses collectively revealed that certain management activities, like the ones perceived to be prioritized-organization strengthening and capacity building in Busuanga and habitat management and fish sanctuaries in Karimunjawa-are the activities or programs that are less felt and experienced. This study is a crucial learning in how collective perceptions can be used moving forward in BCE management strategies in each country as well as a tool for identifying common grounds that can be shared and are transferrable across the CTR.

Supplementary Materials: The following are available online at https:/ /www.mdpi.com/2071-105 0/13/1/127/s1, Texts S1: Factors influencing the awareness and utilization of blue carbon ecosystem services, Table S1: Multiple linear regressions of socio-demographic profile and awareness level of (S1a) mangroves and (S1b) seagrasses' ecosystem services, Table S2: Multiple linear regressions of socio-demographic profile and utilization frequency of (S2a) mangroves and (S2b) seagrasses' provisioning and cultural services, Table S3: Correlation analysis of locals' awareness and utilization of (S3a) mangroves and (S3b) seagrasses' ecosystem services.

Author Contributions: Conceptualization, J.M.D.Q., Y.U., and R.K.; methodology, J.M.D.Q., K.M.L., and Y.U.; validation, J.M.D.Q., K.M.L., and Y.U.; formal analysis, J.M.D.Q. and Y.U., investigation, J.M.D.Q., Y.U., and K.M.L.; resources, J.M.D.Q., K.M.L., and Y.U.; writing—original draft preparation, J.M.D.Q.; writing—review and editing, J.M.D.Q., Y.U., K.M.L., and R.K.; supervision, Y.U. and R.K.; project administration. Y.U. and R.K.; supplementary materials, J.M.D.Q.; funding acquisition, R.K. All authors have read and agreed to the published version of the manuscript.

Funding: This research was funded by JSPS KAKENHI, grant numbers JP20K12398, JP16KK0053, JP17K02105, JP17H01682, Japan Science and Technology Agency (JST) and Japan International Cooperation Agency (JICA) through the Science and Technology Research Partnership for Sustainable Development Program (SATREPS) - Comprehensive Assessment and Conservation of Blue Carbon Ecosystems and Their Services in the Coral Triangle (Blue CARES) project; Toyota Foundation (D17-N-0107); Foundation for Environmental Conservation Measures, Keidanren (2020); Kurita Water and Environment Foundation (20C002).

Informed Consent Statement: Informed consent was obtained from all subjects involved in the study.

Data Availability Statement: The data presented in this study are available on request from the corresponding author. The data are not publicly available since this study is part of an on-going research project.

Acknowledgments: The authors would like to thank the key informants from different government units of Busuanga, Philippines and Karimunjawa National Park, Indonesia for their support in the conduct of the interviews.

Conflicts of Interest: The authors declare that they have no known competing financial interests or personal relationships that could have appeared to influence the work reported in this paper. 


\section{References}

1. Primavera, J.H. Development and Conservation of Philippine Mangroves: Institutional Issues. Ecol. Econ. 2008, 35, 91-106. [CrossRef]

2. Alongi, D.M. Mangrove forests: Resilience, protection from tsunamis, and responses to global climate change. Estuar. Coast. Shelf Sci. 2008, 76, 1-13. [CrossRef]

3. Mukherjee, N.; Sutherland, W.J.; Dicks, L.; Hugé, J.; Koedam, N.; Dahdouh-Guebas, F. Ecosystem Service Valuations of Mangrove Ecosystems to Inform Decision Making and Future Valuation Exercises. PLoS ONE 2014, 9, e111386. [CrossRef] [PubMed]

4. Dasgupta, S.; Islam, S.; Huq, M.; Khan, Z.H.; Hasib, R. Quantifying the protective capacity of mangroves from storm surges in coastal Bangladesh. PLoS ONE 2019, 14, e0214079. [CrossRef] [PubMed]

5. Uddin, S.; de Ruyter van Steveninck, E.; Stuip, M.; Shah, M.A.R. Economic valuation of provisioning and cultural services of a protected mangrove ecosystem: A case study on Sundarbans Reserve Forest, Bangladesh. Ecosyst. Serv. 2013, 5, 88-93. [CrossRef]

6. Crooks, S.; von Unger, M.; Schile, L.; Allen, C.; Whisnant, R. Understanding Strategic Blue Carbon Opportunities in the Seas of East Asia; Report by Silvestrum Climate Associates for Partnerships in Environmental Management for the Seas of East Asia (PEMSEA), Conservation International and The Nature Conservancy, with support from the Global Environment Facility and United Nations Development Program; Partnerships in Environmental Management for the Seas of East Asia (PEMSEA): Quezon City, Philippines, 2017.

7. Howard, J.; Sutton-Grier, A.; Herr, D.; Kleypas, J.; Landis, E.; McLeod, E.; Pidgeon, E.; Simpson, S. Clarifying the role of coastal and marine systems in climate mitigation. Front. Ecol. Environ. 2017, 15, 42-50. [CrossRef]

8. Pidgeon, E. Carbon sequestration by coastal marine habitats: Important missing sinks. In The Management of Natural Coastal Carbon Sinks; Laffoley, D., Grimsditch, G., Eds.; IUCN: Gland, Switzerland, 2009; p. 53.

9. McLeod, E.; Chmura, G.L.; Bouillon, S.; Salm, R.; Björk, M.; Duarte, C.M.; Lovelock, C.E.; Schlesinger, W.H.; Silliman, B.R. A blueprint for blue carbon: Toward an improved understanding of the role of vegetated coastal habitats in sequestering $\mathrm{CO}_{2}$. Front. Ecol. Environ. 2011, 9, 552-560. [CrossRef]

10. Nellemann, C.; Corcoran, E.; Duarte, C.M.; Valdrés, L.; Young, C.D.; Fonseca, L.; Grimsditch, G. Blue Carbon-The Role of Healthy Oceans in Binding Carbon; UN Environment, GRID-Arendal: Arendal, Norway, 2009.

11. Beaumont, N.; Jones, L.; Garbutt, A.; Hansom, J.; Toberman, M. The value of carbon sequestration and storage in coastal habitats. Estuar. Coast. Shelf Sci. 2014, 137, 32-40. [CrossRef]

12. Asaad, I.; Lundquist, C.; Erdmann, M.V.; Costello, M.J. Delineating priority areas for marine biodiversity conservation in the Coral Triangle. Biol. Conserv. 2018, 222, 198-211. [CrossRef]

13. Giri, C.; Ochieng, E.; Tieszen, L.L.; Zhu, Z.; Singh, A.K.; Loveland, T.R.; Masek, J.G.; Duke, N.C. Status and distribution of mangrove forests of the world using earth observation satellite data. Glob. Ecol. Biogeogr. 2010, 20, 154-159. [CrossRef]

14. Alongi, D.M.; Murdiyarso, D.; Fourqurean, J.W.; Kauffman, J.B.; Hutahaean, A.; Crooks, S.; Lovelock, C.E.; Howard, J.B.; Herr, D.; Fortes, M.D.; et al. Indonesia's blue carbon: A globally significant and vulnerable sink for seagrass and mangrove carbon. Wetl. Ecol. Manag. 2015, 24, 3-13. [CrossRef]

15. Long, J.B.; Giri, C. Mapping the Philippines' Mangrove Forests Using Landsat Imagery. Sensors 2011, 11, 2972-2981. [CrossRef] [PubMed]

16. UNEP. National Reports on Seagrass in the South China Sea; UNEP/GEF/SCS Technical Publication No. 12; United Nations Environment Programme: Bangkok, Thailand, 2008.

17. Greenberg, R.; Maldonado, J.E.; Droege, S.; McDonald, M.V. Tidal Marshes: A Global Perspective on the Evolution and Conservation of Their Terrestrial Vertebrates. BioScience 2006, 56, 675. [CrossRef]

18. Chmura, G.L.; Anisfeld, S.C.; Cahoon, D.R.; Lynch, J.C. Global carbon sequestration in tidal, saline wetland soils. Glob. Biogeochem. Cycles 2003, 17, 1111. [CrossRef]

19. Munang, R.; Thiaw, I.; Rivington, M. Ecosystem Management: Tomorrow's Approach to Enhancing Food Security under a Changing Climate. Sustainability 2011, 3, 937-954. [CrossRef]

20. Costanza, R.; de Groot, R.; Sutton, P.; van der Ploeg, S.; Anderson, S.J.; Kubiszewski, I.; Farber, S.; Turner, R.K. Changes in the global value of ecosystem services. Glob. Environ. Chang. 2014, 26, 152-158. [CrossRef]

21. Spalding, M.; Parrett, C.L. Global patterns in mangrove recreation and tourism. Mar. Policy 2019, 110, 103540. [CrossRef]

22. Crooks, S.; Herr, D.; Tamelander, J.; Laffoley, D.; Vandever, J. Mitigating climate change through restoration and management of coastal wetlands and near-shore marine ecosystems: Challenges and opportunities. In Environment Department Papers, No. 121. Marine Ecosystem Series; World Bank: Washington, DC, USA, 2011.

23. Fourqurean, J.W.; Duarte, C.M.; Kennedy, H.; Marbà, N.; Holmer, M.; Mateo, M.A.; Apostolaki, E.T.; Kendrick, G.A.; KrauseJensen, D.; McGlathery, K.J.; et al. Seagrass ecosystems as a globally significant carbon stock. Nat. Geosci. 2012, 5, 505-509. [CrossRef]

24. Duarte, C.M.; Losada, I.J.; Hendriks, I.E.; Mazarrasa, I.; Marbà, N. The role of coastal plant communities for climate change mitigation and adaptation. Nat. Clim. Chang. 2013, 3, 961-968. [CrossRef]

25. Murdiyarso, D.; Purbopuspito, J.; Kauffman, J.B.; Warren, M.W.; Sasmito, S.D.; Donato, D.C.; Manuri, S.; Krisnawati, H.; Taberima, S.; Kurnianto, S. The potential of Indonesian mangrove forests for global climate change mitigation. Nat. Clim. Chang. 2015, 5, 1089-1092. [CrossRef] 
26. Gevaña, D.T.; Pulhin, J.M.; Tapia, M.A. Chapter 13-Fostering climate change mitigation through a community-based approach: Carbon stock potential of community-managed mangroves in the Philippines. In Coastal Management; Krishnamurthy, R.R., Jonathan, M.P., Srinivasalu, S., Glaeser, B., Eds.; Academic Press: London, UK, 2019; pp. 271-282.

27. Wahyudi, A.J.; Rahmawati, S.; Irawan, A.; Hadiyanto, H.; Prayudha, B.; Hafizt, M.; Afdal, A.; Adi, N.S.; Rustam, A.; Hernawan, U.E.; et al. Assessing Carbon Stock and Sequestration of the Tropical Seagrass Meadows in Indonesia. Ocean Sci. J. 2020, 55, 85-97. [CrossRef]

28. Thompson, B.S.; Primavera, J.H.; Friess, D.A. Governance and implementation challengs for mangrove forest Payments for Ecosystem Services (PES): Empirical evidence from the Philippines. Ecosyst. Serv. 2017, 23, 146-155. [CrossRef]

29. Murdiyarso, D.; Sukara, E.; Suprianta, J.; Koropitan, A.; Juliandi, B.; Jompa, J. Creating Blue Carbon Opportunities in the Maritime Archipelago Indonesia; CIFOR Policy Brief No. 3; CIFOR: Bogor, Indonesia, 2018. [CrossRef]

30. Lukman, K.M.; Quevedo, J.M.D.; Kakinuma, K.; Uchiyama, Y.; Kohsaka, R. Indonesia Provincial Spatial Plans on mangroves in era of decentralization: Application of content analysis to 27 provinces and "blue carbon" as overlooked components. J. For. Res. 2019, 24, 341-348. [CrossRef]

31. Herr, D.; Blum, J.; Himes-Cornell, A.; Sutton-Grier, A.E. An analysis of the potential positive and negative livelihood impacts of coastal carbon offset projects. J. Environ. Manag. 2019, 235, 463-479. [CrossRef] [PubMed]

32. Lukman, K.M.; Uchiyama, Y.; Quevedo, J.M.D.; Kohsaka, R. Local awareness as an instrument for management and conservation of seagrass ecosystem: Case of Berau Regency, Indonesia. Ocean Coast. Manag. 2020, 105451. [CrossRef]

33. Quevedo, J.M.D.; Uchiyama, Y.; Kohsaka, R. Perceptions of local communities on mangrove forests, their services and management: Implications for Eco-DRR and blue carbon management for Eastern Samar, Philippines. J. For. Res. 2019, $25,1-11$. [CrossRef]

34. Quevedo, J.M.D.; Uchiyama, Y.; Kohsaka, R. Perceptions of the seagrass ecosystems for the local communities of Eastern Samar, Philippines: Preliminary results and prospects of blue carbon services. Ocean Coast. Manag. 2020, 191, 105181. [CrossRef]

35. Coral Triangle Initiative Climate Change Adaptation Working Group. Regional Workshop on Blue Carbon. Workshop Proceedings Report. 2017. Available online: http:/ / www.coraltriangleinitiative.org/sites/default/files/resources/Regional_CTI_BC_ Workshop_Report.pdf (accessed on 19 July 2020).

36. International Partnership for Blue Carbon (IPBC). Draft Strategic Plan. 2016. Available online: https:/ / bluecarbonpartnership. org/wp-content/uploads/2016/11/IPBC-Strategic-Plan-October-2016.pdf (accessed on 19 July 2020).

37. Quintas-Soriano, C.; Brandt, J.S.; Running, K.; Baxter, C.V.; Gibson, D.M.; Narducci, J.; Castro, A.J. Social-ecological systems influence ecosystem service perception: A Programme on Ecosystem Change and Society (PECS) analysis. Ecol. Soc. 2017, 23. [CrossRef]

38. Millennium Ecosystem Assessment. Ecosystems and Human Well-Being (MEA); Island Press: Washington, DC, USA, $2005 ;$ pp. 25-36.

39. Díaz, S.; Demissew, S.; Carabias, J.; Joly, C.A.; Lonsdale, M.; Ash, N.; Larigauderie, A.; Adhikari, J.R.; Arico, S.; Báldi, A.; et al. The IPBES Conceptual Framework-Connecting nature and people. Curr. Opin. Environ. Sustain. 2015, 14, 1-16. [CrossRef]

40. Kovács, B.; Uchiyama, Y.; Miyake, Y.; Penker, M.; Kohsaka, R. An explorative analysis of landscape value perceptions of naturally dead and cut wood: A case study of visitors to Kaisho Forest, Aichi, Japan. J. For. Res. 2020, 25, 291-298. [CrossRef]

41. Uchiyama, Y.; Kohsaka, R. Cognitive value of tourism resources and their relationship with accessibility: A case of Noto region, Japan. Tour. Manag. Perspect. 2016, 19, 61-68. [CrossRef]

42. Kohsaka, R. Developing biodiversity indicators for cities: Applying the DPSIR model to Nagoya and integrating social and ecological aspects. Ecol. Res. 2010, 25, 925-936. [CrossRef]

43. Ehara, M.; Hyakumura, K.; Sato, R.; Kurosawa, K.; Araya, K.; Sokh, H.; Kohsaka, R. Addressing Maladaptive Coping Strategies of Local Communities to Changes in Ecosystem Service Provisions Using the DPSIR Framework. Ecol. Econ. 2018, 149, 226-238. [CrossRef]

44. Bautista, M.A.; Malolos, G.A.; Magyaya, A.; Palevino, M.L.; Suarez, M.A. Municipality of Busuanga ECAN Resource Management Plan 2017-2022. In Partnership with Municipal Government of Busuanga, Municipal ECAN Board, Palawan Council for Sustainable Development. Available online: https:/ /pcsd.gov.ph/2020/12/11/07-busuanga-ecan-resource-management-plan/ (accessed on 24 December 2020).

45. Hafsaridewi, R.; Fahrudin, A.; Sutrisno, D.; Koeshendrajana, S. Resource management in the Karimunjawa Islands, Central Jawa of Indonesia, through DPSIR approach. Adv. Environ. Sci. 2018, 10, 7-22.

46. Prasetya, J.D.; Ambariyanto, A.; Supriharyono; Purwanti, F. Mangrove Health Index as Part of Sustainable Management in Mangrove Ecosystem at Karimunjawa National Marine Park Indonesia. Adv. Sci. Lett. 2017, 23, 3277-3282. [CrossRef]

47. Ambal, R.G.R.; Duya, M.V.; Cruz, M.A.; Coroza, O.G.; Vergara, S.G.; de Silva, N.; Molinyawe, N.; Tabaranza, B. Key biodiversity areas in the Philippines: Priorities for conservation. J. Threat. Taxa 2012, 4, 2788-2796. [CrossRef]

48. Campbell, S.J.; Kartawijaya, T.; Yulianto, I.; Prasetia, R.; Clifton, J. Co-management approaches and incentives improve management effectiveness in the Karimunjawa National Park, Indonesia. Mar. Policy 2013, 41, 72-79. [CrossRef]

49. Magbanua, F.; D'agnes, L.; Castro, J. Integrated Coastal Management Makes a Difference to Human and Ecosystem Health: Evidence from Philippines; IPOPCORM Monograph Series No. 4; PATH Foundation Philippines Inc: Makati City, Philippines, 2007.

50. Purwanti, F.; Alikodra, H.S.; Basuni, S.; Soedharma, D. Pengembangan Co-Management Taman Nasional Karimunjawa [Co-Management Improvement Karimunjawa National Park]. Ilmu Kelautan 2008, 13, 159-166. 
51. Sarmah, H.K.; Hazarika, B.B. Importance of the size of sample and its determination in the context of data related to the schools of greater Guwahati. Bull. Gauhati Univ. Math. Assoc. 2012, 12, 55-76.

52. Sarmah, H.K.; Hazarika, B.B.; Choudhury, G. An investigation on effect of bias on determination of sample size on the basis of data related to the students of schools of Guwahati. Int. J. Appl. Math. Stat. Sci. 2013, 2, 33-48.

53. Bartlett, J.E., II.; Kotrlik, J.W.; Higgins, C.C. Organizational research: Determining appropriate sample size in survey research. Inf. Technol. Learn. Perform. J. 2001, 19, 43-50.

54. Philippine Statistics Authority. 2015 Census of Population, Report No. 2-Demographic and Socioeconomic Characteristics Palawan. 2017. Available online: https:/ / psa.gov.ph/sites/default/files/17_Palawan.pdf (accessed on 13 December 2020).

55. Fortes, M.D. A review: Biodiversity, distribution and conservation of Philippine seagrasses. Philipp. J. Sci. 2013, 142, 95-111.

56. McGehee, N.; Andereck, K.L. Factors predicting rural residents' support of tourism. J. Travel Res. 2004, 43, 131-140. [CrossRef]

57. Garces, L.; Pido, M.D.; Tupper, M.H.; Silvestre, G. Evaluating the management effectiveness of three marine protected areas in the Calamianes Islands, Palawan Province, Philippines: Process, selected results and their implications for planning and management. Ocean Coast. Manag. 2013, 81, 49-57. [CrossRef]

58. Nurdin, N.; Riani, E.; Djuwita, I.; Budiharsono, S.; Purbayanto, A.; Asmus, H. Challenging for seagrass management in Indonesia. J. Coast. Dev. 2012, 15, 234-242.

59. Puryono, S.; Suryanti, S. Degradation of mangrove ecosystem in Karimunjawa Island based on public perception and management. In Proceedings of the IOP Conference Series: Earth and Environmental Science, Semarang, Indonesia, 30-31 October 2018; Volume 246, p. 012080. [CrossRef]

60. Nehren, U.; Wicaksono, P. Mapping soil carbon stocks in an oceanic mangrove ecosystem in Karimunjawa Islands, Indonesia. Estuar. Coast. Shelf Sci. 2018, 214, 185-193. [CrossRef]

61. Alura, D.P.; Alura, N.C.; Alura, R.P.C. Mangrove forest and seagrass bed of Eastern Samar, Philippines: Extent of damage by typhoon Yolanda. IJNRLS 2015, 2, 30-35.

62. Villamayor, B.M.R.; Rollon, R.N.; Samson, M.S.; Albano, G.M.G.; Primavera, J.H. Impact of Haiyan on Philippine mangroves: Implications to the fate of the widespread monospecific Rhizophora plantations against strong typhoons. Ocean Coast. Manag. 2016, 132, 1-14. [CrossRef]

63. Nordlund, L.M.; Gullström, M. Biodiversity loss in seagrass meadows due to local invertebrate fisheries and harbor activities. Estuar. Coast. Shelf Sci. 2013, 135, 231-240. [CrossRef]

64. Mulyana, E.; Prayoga, M.B.R.; Yananto, A.; Wirahma, S.; Aldrian, E.; Harsoyo, B.; Seto, T.H.; Sunarya, Y. Tropical cyclones characteristics in Southern Indonesia and the impact of extremes rainfall event. In Proceedings of the MATEC Web of Conferences ICDM, Andalas University, Padang, Indonesia, 2-4 May 2018; Volume 229, pp. 1-79. [CrossRef]

65. Kamal, M.; Harjo, H.; Wicaksono, P.; Adi, N.S.; Arjasakusuma, S. Assessment of mangrove forest degradation through canopy fractional cover in Karimunjawa Island, Central Java, Indonesa. Geoplanning J. Geomat. Plan. 2016, 3, 107-116. [CrossRef]

66. Ariyani, N.A.E. Implementation of conservation policy through the protection of life support system in the Karimunjawa National Park. In Proceedings of the E3S Web of Conferences, Semarang, Indonesia, 15-16 August 2018; Volume 31. [CrossRef]

67. Kotijah, S.; Ventyrina, I. Preventive regulations to remove environmental damage to mangrove ecosystem in East Kalimantan, Indonesia. Int. J. Res. Law Econ. Soc. Sci. 2019, 1, 9-19. [CrossRef]

68. Margono, B.A.; Potapov, P.V.; Turubanova, S.; Stolle, F.; Hansen, M.C. Primary forest cover loss in Indonesia over 2000-2012. Nat. Clim. Chang. 2014, 4, 730-735. [CrossRef]

69. Armitage, D. Socio-institutional dynamics and the political ecology of mangrove forest conservation in Central Sulawesi, Indonesia. Glob. Environ. Chang. 2002, 12, 203-217. [CrossRef]

70. UNEP. Importance of Mangroves to People: A Call to Action; van Bochove, J., Sullivan, E., Nakamura, T., Eds.; United Nations Environment Programme World Conservation Monitoring Centre: Cambridge, UK, 2014; 128p.

71. Amri, L.; Setiadi, D.; Qayim, I.; Djokosetiyanto, D. Nutrient content of seagrass Enhalus acoroides leaves in Barranglompo and Bonebatang Islands: Implication to increased anthropogenic pressure. Indones. J. Mar. Sci. 2011, 16, 181-186. [CrossRef]

72. Unsworth, R.K.F.; Ambo-Rappe, R.; Jones, B.L.; La Nafie, Y.A.; Irawan, A.; Hernawan, U.E.; Moore, A.M.; Cullen-Unsworth, L.C. Indonesia's globally significant seagrass meadows are under widespread threat. Sci. Total. Environ. 2018, 634, 279-286. [CrossRef]

73. Austin, R.L.; Eder, J.F. Environmentalism, Development, and Participation on Palawan Island, Philippines. Soc. Nat. Resour. 2007, 20, 363-371. [CrossRef]

74. D'Agnes, L.; D'Agnes, H.E.; Schwartz, J.B.; Amarillo, M.L.; Castro, J. Integrated management of coastal resources and human health yields added value: A comparative study in Palawan. Environ. Conserv. 2010, 37, 398-409. [CrossRef]

75. Abdullah, K.; Said, A.M.; Omar, D. Community-based Conservation in Managing Mangrove Rehabilitation in Perak and Selangor. Procedia Soc. Behav. Sci. 2014, 153, 121-131. [CrossRef]

76. Glaser, M.; Baitoningsih, W.; Ferse, S.C.; Neil, M.; Deswandi, R. Whose sustainability? Top-down participation and emergent rules in marine protected area management in Indonesia. Mar. Policy 2010, 34, 1215-1225. [CrossRef]

77. Kohsaka, R.; Matsuoka, H. Analysis of Japanese municipalities with Geopark, MAB, and GIAHS certification: Quantitative approach to official records with text-mining methods. SAGE Open 2015, 5, 1-10. [CrossRef]

78. Kohsaka, R.; Matsuoka, H.; Uchiyama, Y.; Rogel, M. Regional management and biodiversity conservation in GIAHS: Text analysis of municipal strategy and tourism management. Ecosyst. Health Sustain. 2019, 5, 124-132. [CrossRef] 